The Politics of Written Language in the Arab World 


\section{Studies in \\ Semitic Languages and Linguistics}

Editorial Board

Aaron D. Rubin and Ahmad Al-Jallad

VOLUME 90

The titles published in this series are listed at brill.com/ssl 


\title{
The Politics of Written Language in the Arab World
}

\author{
Writing Change
}

Edited by

Jacob Høigilt

Gunvor Mejdell

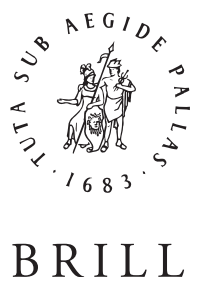




\section{B R I L L OPE N}

This is an open access title distributed under the terms of the CC-BY-NC License, which permits any non-commercial use, distribution, and reproduction in any medium, provided the original author(s) and source are credited.

Library of Congress Cataloging-in-Publication Data

Names: Hoigilt, Jacob editor. | Mejdell, Gunvor editor.

Title: The politics of written language in the Arab world : writing change / edited by Jacob Hoigilt, Gunvor Mejdell.

Description: Leiden ; Boston : Brill, 2017. | Series: Studies in semitic languages and linguistics ; volume 90 Includes bibliographical references and index.

Identifiers: LCCN 2017028168 (print) | LCCN 2017031960 (ebook) | ISBN 9789004346178 (E-book) | ISBN 9789004346161 (hardback : alk. paper)

Subjects: LCSH: Written communication-Arab countries. | Arabic language-

Written Arabic. | Arabic language-Political aspects. | Arabic language-Social aspects. | Arabic language-Dialects-Egypt. | Arabic

language-Dialects-Morocco.

Classification: LCC P211.3.A65 (ebook) | LCC P211.3.A65 P65 2017 (print)|

DDC 306.442/927-dc23

LC record available at https://lccn.loc.gov/2017028168

Typeface for the Latin, Greek, and Cyrillic scripts: “Brill”. See and download: brill.com/brill-typeface.

\section{ISSN 0081-8461}

ISBN 978-90-04-34616-1 (hardback)

ISBN 978-90-04-34617-8 (e-book)

Copyright 2017 by the Editors and Authors.

This work is published by Koninklijke Brill Nv. Koninklijke Brill NV incorporates the imprints Brill, Brill Hes \& De Graaf, Brill Nijhoff, Brill Rodopi and Hotei Publishing.

Koninklijke Brill NV reserves the right to protect the publication against unauthorized use and to authorize dissemination by means of offprints, legitimate photocopies, microform editions, reprints, translations, and secondary information sources, such as abstracting and indexing services including databases. Requests for commercial re-use, use of parts of the publication, and/or translations must be addressed to Koninklijke Brill NV.

This book is printed on acid-free paper and produced in a sustainable manner. 


\section{Contents}

Preface VII

List of Contributors IX

Introduction 1

Jacob Høigilt and Gunvor Mejdell

$1 \quad$ A Language for the People?

Quantitative Indicators of Written dārija and 'āmmiyya in Cairo and Rabat 18

Kristian Takvam Kindt and Tewodros Aragie Kebede

$2 \quad$ Diglossia as Ideology 41

Kristen Brustad

3 Changing Norms, Concepts and Practices of Written Arabic

A 'Long Distance' Perspective 68

Gunvor Mejdell

4 Contemporary dārija Writings in Morocco

Ideology and Practices 90

Catherine Miller

5 Morocco: An Informal Passage to Literacy in dārija (Moroccan

Arabic) $\quad 116$

Dominique Caubet

6 Adab sākhir (Satirical Literature) and the Use of Egyptian

Vernacular 142

Eva Marie Håland

$7 \quad$ Dialect with an Attitude

Language and Criticism in New Egyptian Print Media 166 Jacob Høigilt

8 Writing Oral and Literary Culture

The Case of the Contemporary Moroccan zajal 190

Alexander Elinson 
9 The Politics of Pro-'ãmmiyya Language Ideology in Egypt 212 Mariam Aboelezz

10 Moralizing Stances

Discursive Play and Ideologies of Language and Gender in Moroccan Digital Discourse 239

Atiqa Hachimi

11 The Language of Online Activism

A Case from Kuwait 266

Jon Nordenson

12 The Oralization of Writing

Argumentation, Profanity and Literacy in Cyberspace 290

Emad Abdul Latif

Index 309 


\section{Preface}

This volume comes out of a four year research project (The sociology and ideology of language change in the Arab world) based in Oslo, but involving scholars from - besides Norway - Egypt and Morocco, France and Britain, the Us and Canada. Thanks to a generous research grant from the Research Council of Norway, we have been able to meet in three workshops - in Cairo, Oslo and Rabat - in order to arrive at a conceptual and empirical framework for the project and to discuss preliminary versions of the contributions to this volume. We also designed the issues and questions for two large-scale surveys on attitudes and practices concerning written Arabic, carried out in Cairo and Rabat. The results of these surveys have already been made publicly available in two tabulation reports published by the Norwegian research institute Fafo: Language and Change in Egypt: Social and Cultural Indicators Survey and Language and Social Survey in Morocco.

The editors, dr. Jacob Høigilt (senior researcher at the Peace Research Institute Oslo) and professor Gunvor Mejdell (University of Oslo), have thoroughly enjoyed the company of and scholarly discussions with our colleagues. We believe our cooperative efforts have resulted in an interesting, highly relevant and valuable volume on writing Arabic, its politics and practices.

Several institutions deserve thanks for their support and facilitation throughout the project. First, we would like to thank the Research Council of Norway for a grant that has financed this four-year, international research project on Arabic sociolinguistics (RCN project no. 213473). The grant has also made it possible for us to publish this book under Brill's Open Access program, which we think is particularly important to facilitate scholarly contact between Arab, European and American academia. In Egypt, the always friendly staff at the Netherlands-Flemish Institute in Cairo (NVIC) kindly offered to host us during our first workshop. The Institute provided a perfect venue for three days of intense deliberations, and a tranquil haven in the centre of Cairo; we are grateful to everybody there, in particular the director, Rudolf de Jong, and the office manager, Tilly Mulder. In Morocco, we would like to thank the Faculty of Educational Sciences at Muhammad v University, Rabat and its dean Abdelhanine Belhaj for their generosity in connection with our third workshop in Rabat. In addition to contributing to the workshop in Rabat, Ahmed Ech-Charfi at Muhammad v University took care of all the organizing and liaison with the University; his kind assistance and good spirits were highly appreciated by all. In Norway, we would like to thank the research institute Fafo for hosting the project in the initial stages and for its valuable work in relation to the surveys in 
Cairo and Rabat. The Department for Culture Studies and Oriental Languages at the University of Oslo kindly hosted the second workshop as well as the $\mathrm{PhD}$ fellowship included in the project. The Peace Research Institute Oslo has been the main host institution for the project. Its magnificent administrative staff has provided indispensable support throughout, always with a smile; Jacob is eternally grateful to Pål Torjus Halsne, Lars Even Andersen and Lorna Quilario Sandberg for their help and advice. Finally, we would like to thank Maarten Frieswijk at Brill for his interest in the book and all his help and support during the publication process.

Jacob Høigilt and Gunvor Mejdell

Oslo, 9 February 2017 


\title{
List of Contributors
}

\author{
Emad Abdul Latif
}

is associate professor of Arabic at Qatar University, http:/qu.academia.edu/ EmadAbdullatif

\section{Mariam Aboelezz}

is an independent researcher based in Lancaster, $\mathrm{UK}$, http://lancaster.academia .edu/MariamAboelezz/Papers

\section{Kristen Brustad}

is associate professor of Arabic at the University of Texas at Austin, UsA, and former chair of the department of Middle Eastern studies at the same university, https://www.utexas.edu/cola/depts/mes/faculty/kb6796

\section{Dominique Caubet}

is professor emerita at INALCO, Paris, https://inalco.academia.edu/

DominiqueCaubet.

\section{Alexander Elinson}

is associate professor of Arabic language and literature at Hunter college, City University of New York, UsA, http://www.hunter.cuny.edu/classics/arabic/ faculty

\section{Atiqa Hachimi}

is associate professor of Women's and Gender Studies and African Studies at the University of Toronto, Scarborough, Canada, http://www.utsc.utoronto.ca/ hcs/atiqa-hachimi

Jacob Høigilt

is senior researcher at the Peace Research Institute Oslo (PRIO) and adjunct associate professor of Middle East studies at the Department of Culture Studies and Oriental Languages, University of Oslo

\section{Eva Marie Håland}

is a PhD student at the Department of Culture Studies and Oriental Languages, University of Oslo 
Tewodros Aragie Kebede

is a researcher at the Norwegian research institute Fafo, Oslo, Norway, http:// www.fafo.no/index.php?option=com_zoo\&task=item\&item_id=4681

\&Itemid $=211 \&$ lang $=$ en

\section{Kristian Takvam Kindt}

is a researcher at the Norwegian research institute Fafo, Oslo, Norway, http:// www.fafo.no/index.php?option=com_zoo\&task=item\&item_id=4713

\&Itemid $=1089 \&$ lang $=\mathrm{en}$

\section{Gunvor Mejdell}

is Professor of Arabic at the Department of Culture Studies and Oriental Languages, University of Oslo

\section{Catherine Miller}

is director of Institut de recherches et d'études sur le monde arabe et musulman (IREMAM), Aix-en-Provence, France, http://iremam.cnrs.fr/spip.php ?article388

Jon Nordenson

is senior researcher at the Department of Culture Studies and Oriental Languages, University of Oslo 